\title{
DESAIN PINTU MASUK BUBU LIPAT BERDASARKAN ASPEK TINGKAH LAKU RAJUNGAN
}

\author{
Design of Collapsible Trap Entrance Based on Behaviour of Blue Swimming Crab
}

\section{Oleh:}

Adi Susanto ${ }^{* 1,2}$, Hery Sutrawan Nurdin ${ }^{1,2}$, Ririn Irnawati1,2, Mochammad Riyanto ${ }^{3}$, Mohammad Ependi1, Fahresa Nugraheni Supadminingsih ${ }^{1}$, Asep Hamzah ${ }^{1}$, Hendrawan Syafrie $^{1}$

\footnotetext{
1Program Studi Ilmu Perikanan, Fakultas Pertanian Universitas Sultan Ageng Tirtayasa, Jl. Raya Palka Km. 3 Sindangsari Kec. Pabuaran Kab. Serang

Telp.0254-280330,adisusanto@untirta.ac.id, herysutrawannurdin@gmail.com,ririn.irnawati@untirta.ac.id, ependimohammad@gmail.com, fahresan@gmail.com, asep.hamzah@untirta.ac.id,a.syafrie@gmail.com 2Pusat Unggulan Iptek Perguruan Tinggi Ketahanan Pangan-Inovasi Pangan Lokal, Jl. Raya Palka Km. 3 Sindangsari Kec. Pabuaran Kab. Serang Telp. 0254-280330

${ }^{3}$ Departemen Pemanfaatan Sumberdaya Perikanan Fakultas Perikanan dan Ilmu Kelautan Institut Pertanian Bogor Jl. Agathis Kampus IPB Dramaga Bogor. riyanto.psp@gmail.com

*Korespondensi: adisusanto@untirta.ac.id
}

Diterima: 22 Juli 2021; Disetujui: 23 September 2021

\begin{abstract}
Blue swimming crab fishing using collapsible traps is widely used by fishers because they can catch live crabs and has high selectivity. However, the passive fishing operation causes low fishing productivity. The entrance design has a significant influence on successful fishing operations using collapsible traps. When the mesh size of the net and the inclination angle on the entrance do not consider the crab's behavior, it will cause the crab fail to be trapped. This study aims to define the effective entrance design for catching crabs using the collapsible trap. The study was conducted in a laboratory using three mesh sizes, including 1.00, 1.25, and 1.50 inches with $30^{\circ}, 40^{\circ}$, and $50^{\circ}$ inclination angles. Each treatment combination uses different individual crab. All experiments were performed at night in an aquarium equipped with an infrared camera. Differences in mesh size and inclination angle affect the crab's success rate and crawling speed in crossing the net frame. The results showed that the highest percentage of crabs that successfully crossed the net field was found at 1.25-inch mesh with an angle of $40^{\circ}$. The highest crawling speed was obtained at the same mesh size and inclination angle. The mesh size of 1.25 inches with an angle of $40^{\circ}$ is expected to increase the effectiveness of catching crabs with folding traps.
\end{abstract}

Keywords: trap, effectiveness, mesh size, fishing, response.

\section{ABSTRAK}

Penangkapan rajungan menggunakan bubu lipat banyak digunakan nelayan karena memiliki kualitas hasil tangkapan yang baik (hidup) dan selektif. Meskipun demikian, sifat pengoperasiannya yang pasif menyebabkan produktivitas penangkapannya relatif rendah. Salah satu faktor yang dapat meningkatkan keberhasilan penangkapan rajungan menggunakan bubu lipat yaitu kesesuaian desain pintu masuk yang digunakan. Ukuran mata jaring dan sudut kemiringan pintu masuk bubu yang tidak sesuai dengan tingkah laku rajungan akan menyebabkan rajungan gagal tertangkap. Penelitian ini bertujuan untuk menentukan desain pintu masuk bubu yang lebih efektif untuk 
rajungan. Penelitian dilakukan di laboratorium menggunakan tiga ukuran mata jaring yaitu 1,$00 ; 1,25$ dan 1,50 inci dengan sudut kemiringan $30^{\circ}, 40^{\circ}$ dan $50^{\circ}$. Setiap kombinasi perlakuan menggunakan individu rajungan yang berbeda. Penelitian dilakukan pada malam hari dalam akuarium yang dilengkapi dengan kamera infra merah. Perbedaan ukuran mata jaring dan sudut kemiringan berpengaruh terhadap tingkat keberhasilan dan kecepatan merayap rajungan dalam melintasi bidang jaring. Hasil penelitian menunjukkan persentase rajungan yang berhasil melintasi bidang jaring paling tinggi diperoleh pada penggunaan mata jaring 1,25 inci dengan sudut kemiringan $40^{\circ}$. Rata-rata kecepatan merayap paling tinggi juga diperoleh pada ukuran mata jaring dan sudut kemiringan yang sama. Penggunaan mata jaring 1,25 inci dengan sudut kemiringan $40^{\circ}$ diharapkan dapat meningkatkan efektivitas penangkapan rajungan dengan bubu lipat.

Kata kunci: bubu, efektivitas, mata jaring, penangkapan, respon.

\section{PENDAHULUAN}

Rajungan (Portunus pelagicus) merupakan salah satu jenis krustrasea yang memiliki nilai ekonomis tinggi (Kembaren \& Surahman 2018; Susanto et al. 2019) dengan permintaan ekspor yang terus meningkat. Rajungan menjadi komoditas ekspor utama Indonesia ke Amerika Serikat dengan nilai devisa mencapai 246,14 juta dolar (US\$) pada tahun 2015 (APRI 2016). Volume produksi kepiting/ rajungan Indonesia mencapai 169.795 ton pada tahun 2017 atau naik 74\% dibandingkan tahun 2016 (Luhur et al. 2020). Suhana (2020) menyatakan bahwa selama periode tahun 2010-2019 volume impor kepiting dan rajungan USA dari Indonesia meningkat ratarata $2,91 \%$ per tahun. Sumber utama produksi rajungan masih mengandalkan hasil tangkapan di alam dengan alat tangkap dominan berupa bubu dan jaring insang. Bubu lipat merupakan alat tangkap rajungan yang memiliki selektivitas lebih tinggi dibandingkan dengan alat tangkap jaring kejer (gillnet), garuk dan jaring arad sehingga lebih ramah lingkungan (Marliana et al. 2015, Mahiswara et al. 2018).

Penggunaan bubu untuk menangkap rajungan memiliki beberapa keunggulan antara lain rajungan yang tertangkap dalam kondisi hidup, ramah lingkungan dan dapat menjangkau daerah penangkapan yang lebih luas. Meskipun demikian, produktivitas penangkapan rajungan menggunakan bubu cenderung lebih rendah dibandingkan dengan alat tangkap jaring insang maupun garuk. Putri et al. (2013) menyatakan bahwa jumlah hasil tangkapan rajungan maksimal dalam satu unit bubu sebanyak dua ekor rajungan. Rendahnya efisiensi dan efektivitas bubu dapat ditingkatkan melalui modifikasi desain pintu masuk (Irnawati et al. 2018; Jayanto et al. 2018). Konstruksi mulut bubu yang ideal akan memberikan kemudahan krustase dalam merayap sehingga menurunkan peluang kegagalan krustase masuk ke dalam bubu (Atar et al. 2002).

Hasanah et al. (2017) menyatakan bahwa penentuan desain alat tangkap harus menyesuaikan dengan tingkah laku target tangkapan. Desain pintu masuk pada bubu menjadi aspek penting yang harus diperhatikan untuk meningkatkan efektivitasnya berdasarkan hasil penelitian tingkah laku yang dilakukan. Hasil penelitian Fitri et al. (2017) menunjukkan bahwa semakin curam sudut kemiringan maka kepiting bakau cenderung tidak dapat melintasi mulut bubu. Aditya et al. (2020) menyatakan bahwa kemiringan sudut pintu masuk bubu dengan mata jaring 1,25 inci berpengaruh signifikan terhadap jumlah rajungan yang masuk ke bubu. Rajungan yang tertangkap oleh bubu dengan sudut kemiringan tinggi $\left(40^{\circ}\right)$ lebih rendah jika dibandingkan dengan jumlah rajungan yang tertangkap pada bubu dengan sudut kemiringan pintu masuk yang landai $\left(20^{\circ}\right)$.

Sudut kemiringan dan ukuran mata jaring yang digunakan pada pintu masuk bubu sangat menentukan keberhasilan kepiting atau rajungan tertangkap pada bubu (Boutson et al. 2008). Bubu yang digunakan nelayan di Teluk Banten memiliki kemiringan pintu masuk antara $20-25^{\circ}$ dengan mata jaring berukuran 1,0 inci. Namun demikian, pemilihan desain pintu masuk tersebut belum didasarkan pada aspek tingkah laku rajungan sehingga efektivitas penangkapannya masih rendah. Li et al. (2006) mengatakan bahwa kesesuaian desain pintu masuk akan meningkatkan efisiensi dan efektivitas penangkapan menggunakan bubu. Penelitian ini bertujuan untuk menentukan desain pintu masuk bubu rajungan yang lebih ideal berdasarkan ukuran mata jaring dan sudut kemiringan yang berbeda. Desain pintu masuk yang ideal diharapkan akan meningkat- 
kan efektivitas penangkapan rajungan dengan bubu lipat sehingga dapat meningkatkan produktivitas penangkapan rajungan di Teluk Banten khususnya dan wilayah lain di Indonesia.

\section{METODE}

Penelitian dilakukan di Laboratorium Budidaya Perairan, Jurusan Perikanan Fakultas Pertanian Universitas Sultan Ageng Tirtayasa. Pengumpulan data dilakukan pada bulan Mei hingga November 2020 melalui ujicoba laboratorium.

Rajungan yang digunakan sebanyak 94 ekor berasal dari hasil tangkapan nelayan bubu di perairan Teluk Banten dengan lebar karapas antara 100-152 mm. Ukuran tersebut digunakan berdasarkan kriteria rajungan yang boleh ditangkap di Indonesia sesuai Permen KP No. 71 tahun 2021. Sebelum digunakan dalam penelitian, rajungan dipelihara dalam bak beton berukuran panjang $190 \mathrm{~cm}$, lebar $170 \mathrm{~cm}$ dan tinggi $60 \mathrm{~cm}$. Rajungan diberi makan pada pagi dan sore hari berupa potongan ikan pepetek. Kualitas air bak pemeliharaan disesuaikan dengan kebutuhan optimum rajungan yaitu suhu berkisar $28 \pm 2$ ${ }^{\circ} \mathrm{C}$ yang diukur menggunakan termometer digital (Hailea HL 01F) dan salinitas antara 27 $\pm 5 \%$ yang diukur menggunakan refraktometer (Atago Master-S/Mill M). Pemeliharaan dilakukan selama tujuh hari agar rajungan beradaptasi dengan lingkungan laboratorium, sudah tidak menunjukkan tingkah laku stres hingga siap digunakan dalam penelitian. Rajungan yang siap digunakan dalam penelitian dicirikan dengan gerakan yang gesit, agresif dan menghabiskan makanan yang diberikan.

Penelitian dilaksanakan di dalam akuarium kaca dengan ukuran panjang $100 \mathrm{~cm}$, dengan lebar dan tinggi masing-masing $40 \mathrm{~cm}$. Panjang akuarium $100 \mathrm{~cm}$ lebih besar dibandingkan penelitian Sun et al. (2017) dan sudah ideal untuk pengamatan respons dan tingkah laku alamiah rajungan secara individu terhadap desain pintu masuk yang digunakan. Dalam akurium dengan panajang $100 \mathrm{~cm}$, rajungan dapat bergerak bebas ke segala arah. Rajungan termasuk dalam kelompok hewan teritorial sehingga area pengamatan yang lebih luas akan menghasilkan informasi tingkah laku individu alami rajungan yang lebih representatif. Akuarium diisi air laut dengan ketinggian $30 \mathrm{~cm}$ sehingga lintasan pintu masuk yang digunakan terendam sempurna. Air laut diperoleh dari perairan Teluk Banten yang telah mengalami proses penyaringan dan aerasi. Suhu air laut selama penelitian dijaga pada kisaran $28 \pm 2{ }^{\circ} \mathrm{C}$ dan salinitas sebesar $27 \pm 5 \%$.

Lintasan masuk bubu terbuat dari bahan jaring polietilen (D9, diameter 0,8 $\mathrm{mm}$ ) dengan lebar $40 \mathrm{~cm}$ dan panjang $20 \mathrm{~cm}$. Penelitian menggunakan tiga ukuran mata jaring yaitu 1,$0 ; 1,25$ dan 1,50 inci yang disusun membentuk kotak. Ukuran mata jaring 1,25 dan 1,50 inci yang digunakan dalam penelitian ini merupakan pengembangan yang dilakukan untuk mengantisipasi ukuran dactylus pada kaki renang rajungan yang semakin besar seiring bertambahnya ukuran rajungan. Lintasan masuk bubu dipasang pada tiga sudut kemiringan berbeda yaitu $30^{\circ}, 40^{\circ}$, dan $50^{\circ}$. Sudut ini dipilih berdasarkan hasil penelitian Archdale et al. (2003), Susanto et al. (2014), Fitri et al. (2017) dan Aditya et al. (2020) untuk menghasilkan kemiringan yang mudah dilintasi dan meminimumkan rajungan keluar dari pintu masuk yang sama. Pada bagian ujung akuarium pengamatan, diletakkan umpan alami berupa ikan pepetek dengan berat $50 \mathrm{~g}$ yang dibungkus kain kasa. Umpan ini berguna untuk menarik perhatian rajungan agar bergerak melewati lintasan pintu masuk bubu yang digunakan seperti disajikan pada Gambar 1.

Akuarium pengamatan dilengkapi dengan kamera infra merah (Samsung, 2.0 MP AHD camera, lens $1,56 \mathrm{~mm}$, wave length $=850$ $\mathrm{nm}$ ) pada bagian atasnya yang digunakan untuk merekam pola merayap rajungan saat melintas. Kamera dihubungkan dengan monitor (Acer, X163W) dan digital video recorder (HIK VISION, DVR DS-7204HQHIK1) sehingga dapat diamati secara langsung dan disimpan untuk analisis lebih lanjut. Rajungan yang telah digunakan dalam pengamatan dikembalikan ke bak pemeliharaan. Air laut dalam akuarium pengamatan diganti setiap hari untuk mengurangi risiko rajungan stres dan mati karena kondisi lingkungan yang tidak sesuai.

Rancangan acak lengkap faktorial $3 \times 3$ digunakan dalam penelitian untuk menguji beda nyata antar perlakuan, yaitu 3 ukuran mata jaring dan 3 sudut kemiringan bidang lintasan. Faktor pertama berupa ukuran mata jaring dan faktor kedua adalah sudut kemiringan pemasangan lintasan pintu masuk. Ukuran mata jaring dibagi menjadi tiga taraf yaitu 1,0 inci; 1,25 inci dan 1,5 inci. Sudut kemiringan juga terdiri atas tiga taraf yaitu sudut $30^{\circ}, 40^{\circ}$ dan $50^{\circ}$ sehingga menghasilkan sembilan kombinasi perlakuan yang dicobakan dalam penelitian. Pelaksanaan penelitian 
dilakukan pada malam hari mulai pukul 20.0002.00 WIB sesuai dengan waktu aktif rajungan (Azra \& Ikhwanuddin 2015; Sun et al. 2017). Pengambilan data dari setiap kombinasi perlakuan dilakukan dengan menggunakan 30 ekor rajungan yang berbeda. Proses pengambilan data dilakukan per individu rajungan. Individu rajungan yang tidak bergerak dari posisi awal hingga 60 menit pengamatan berlangsung akan diganti dengan individu lainnya (Liu et al. 2019). Rajungan yang sudah digunakan diistirahatkan minimal 24 jam untuk memulihkan kondisi dan menghindari stres (Zhu et al. 2021). Rajungan dapat digunakan kembali jika sudah tidak menunjukkan gejala stres akibat perlakuan antara lain gerakan yang aktif, nafsu makan normal dan agresif ketiga ada rajungan lain yang mendekat. Data yang dikumpulkan antara lain jumlah rajungan yang berhasil dan gagal melewati bidang lintasan, waktu yang dibutuhkan rajungan melewati bidang lintasan, serta pola dan tingkah laku rajungan ketika melewati bidang lintasan.

Data yang diperoleh dianalisis secara deskriptif dalam bentuk grafik dan gambar. Analisis ragam (Anova) digunakan untuk menentukan pengaruh perbedaan ukuran mata jaring dan sudut kemiringan terhadap waktu dan kecepatan merayap rajungan melewati lintasan bubu. Uji lanjut Tukey digunakan untuk menentukan kombinasi perlakuan yang memberikan pengaruh nyata terhadap waktu dan kecepatan rajungan merayap melintasi bidang jaring. Pola dan tingkah laku rajungan yang berhasil melewati bidang lintasan selama penelitian dianalisis menggunakan software video tracking and trajectory Kinovea 0.8.15 (Susanto et al. 2018).

Pemilihan ukuran mata jaring dan sudut kemiringan yang optimal dilakukan berdasarkan persentase keberhasilan jumlah rajungan yang melewati lintasan jaring, kecepatan merayap rajungan dan persentase rajungan yang gagal melewati bidang jaring. Semakin tinggi persentase rajungan yang melewati bidang jaring (persentase kegagalan rendah) dengan kecepatan merayap yang tinggi mengindikasikan kombinasi ukuran mata jaring dan sudut kemiringan yang ideal untuk digunakan pada bubu lipat. Persentase keberhasilan dan kegagalan rajungan dalam melewati bidang jaring dihitung dengan formula sebagai berikut.

Persentase keberhasilan $=\frac{k i}{N} \times 100 \%$

Persentase kegagalan $=\frac{g i}{N} \times 100 \%$

dengan:

$\mathrm{ki}$ : jumlah rajungan yang berhasil melewati lintasan jaring pada kombinasi perlakuan ke-i

gi : jumlah rajungan yang gagal melewati lintasan jaring pada kombinasi perlakuan ke-i

$\mathrm{N}$ : jumlah total rajungan yang digunakan dalam penelitian pada setiap kombinasi pelakuan ke-i

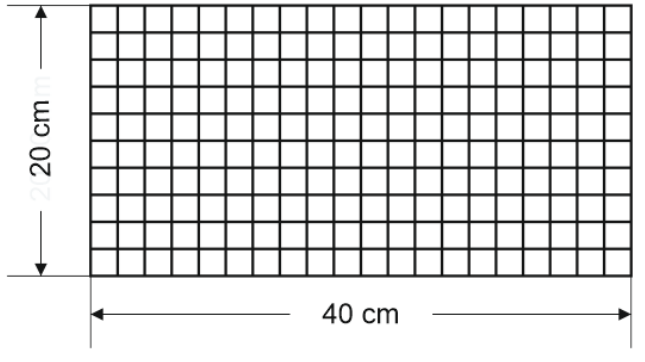

(a)

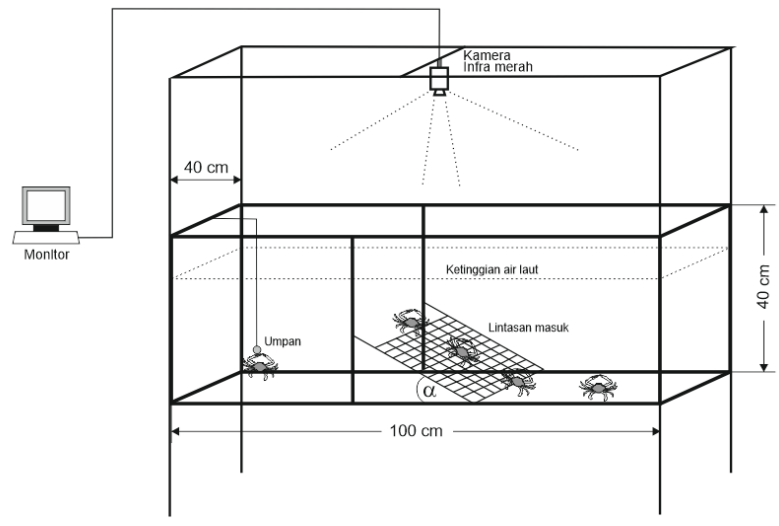

(b)

Gambar 1 Lintasan pintu masuk bubu (a) dan desain akuarium (b) yang digunakan dalam penelitian 
HASIL

\section{Keberhasilan rajungan melewati lintasan jaring}

Hasil penelitian menunjukkan bahwa berdasarkan ukuran mata jaring yang digunakan pada semua sudut kemiringan yang berbeda, maka ukuran mata jaring 1,25 inci memiliki tingkat keberhasilan paling tinggi untuk dilewati rajungan. Pada semua sudut kemiringan yang digunakan, rata-rata sebanyak 27 ekor dari 30 ekor (90\%) rajungan yang digunakan berhasil melewati bidang jaring seperti disajikan pada Gambar 2. Sementara itu, ukuran mata jaring 1,00 dan 1,50 inci memiliki tingkat keberhasilan yang sama, masing-masing 24 ekor dari 30 ekor atau sebesar $80 \%$.

\section{Kecepatan merayap rajungan}

Kecepatan rata-rata merayap rajungan paling tinggi ketika melintasi bidang lintasan dengan sudut kemiringan $30^{\circ}$, dengan mata jaring 1,00 inci sebesar $2,4 \mathrm{~cm} / \mathrm{s}$. Sementara itu kecepatan paling rendah diperoleh pada saat rajungan merayap pada bidang lintasan dengan sudut kemiringan $50^{\circ}$, dengan mata jaring 1,50 inci sebesar $1,3 \mathrm{~cm} / \mathrm{s}$. Kecepatan rata-rata rajungan merayap pada setiap sudut kemiringan bidang lintasan per ukuran mata jarring, disajikan pada Gambar 3.
Hasil uji anova menunjukkan bahwa perbedaan sudut kemiringan memberikan pengaruh yang signifikan terhadap kecepatan merayap rajungan melewati bidang jaring $(p=$ 0,031 ) seperti disajikan pada Tabel 1 . Hal ini berhubungan dengan tingkat kesulitan rajungan dalam melewati celah mata jaring saat dipasang pada sudut yang curam. Rajungan menggunakan kaki jalan di bagian depan dengan cara mengaitkan bagian dactylus-nya pada kaki mata jaring (bar) dan kemudian menarik tubuhnya perlahan-lahan hingga melewati bidang lintasan. Pada saat merayap, bagian dactylus kaki jalan bagian belakang ditekuk sedemikian rupa sehingga dapat bertumpu pada salah satu atau dua bar mata jaring sehingga rajungan lebih cepat untuk merayap melewati bidang lintasan seperti disajikan pada Gambar 4.

Selain menggunakan kaki jalan untuk merayap, rajungan juga menggunakan kaki renangnya saat harus melintasi bidang jaring yang lebih curam. Posisi pemasangan bidang lintasan yang curam menyebabkan mata jaring menjadi celah yang lebih sempit sehingga bagian dactylus kaki renang rajungan akan tersangkut ketika berusaha ditarik saat merayap seperti disajikan pada Gambar 5.
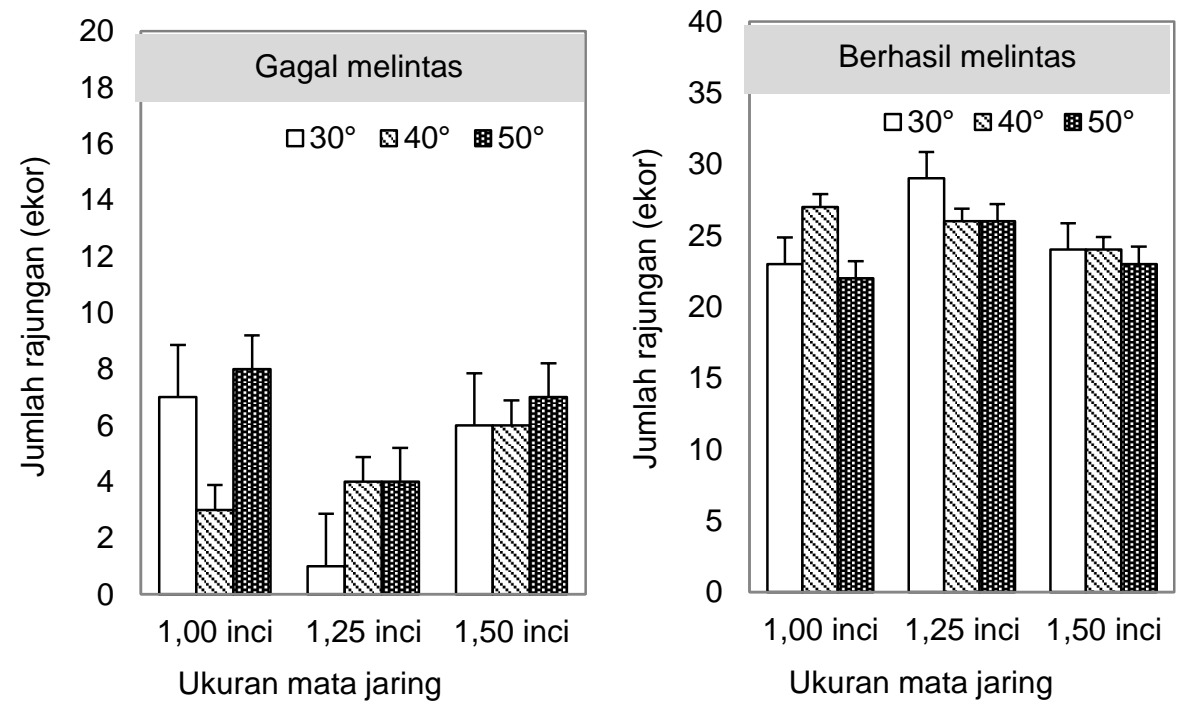

Gambar 2 Jumlah rajungan yang berhasil dan gagal melewati bidang lintasan pada ukuran mata jaring dan sudut kemiringan berbeda ( $\square$ sudut $30^{\circ}, \mathbf{\Delta}$ sudut $40^{\circ}$, $\mathbf{B}$ sudut $50^{\circ}$ ) 


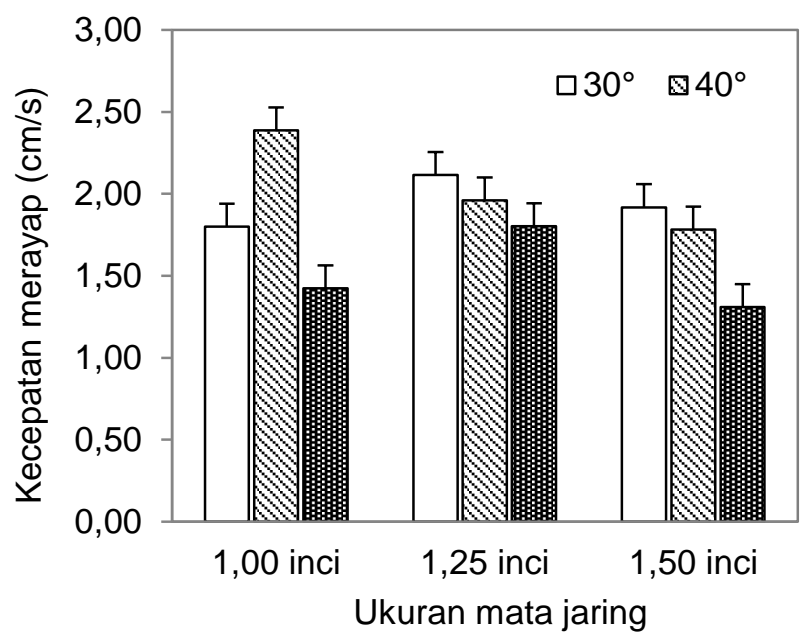

Gambar 3 Kecepatan merayap rajungan pada mata jaring dan sudut kemiringan berbeda( $\square$ sudut $30^{\circ}$, $\mathbf{Q}$ sudut $40^{\circ}, \mathbf{B}$ sudut $50^{\circ}$ )

Tabel 1 Tabel sidik ragam (anova) pengaruh ukuran mata jaring dan sudut kemiringan terhadap kecepatan merayap

\begin{tabular}{lrrllll}
\hline \multicolumn{1}{c}{ Source of Variation } & \multicolumn{1}{c}{$S S$} & \multicolumn{1}{c}{$d f$} & MS & \multicolumn{1}{c}{$F$} & $P$-value & F crit \\
\hline Ukuran mata jaring & 9,7977 & 2 & 4,8988 & 2,3877 & 0,0938 & 3,0304 \\
Sudut kemiringan & 14,4117 & 2 & 7,2059 & 3,5121 & 0,0312 & 3,0304 \\
Interaksi & 9,7164 & 4 & 2,4291 & 1,1839 & 0,3182 & 2,4062 \\
Galat & 535,5027 & 261 & 2,0517 & & & \\
Total & 569,4285 & 269 & & & & \\
\hline
\end{tabular}

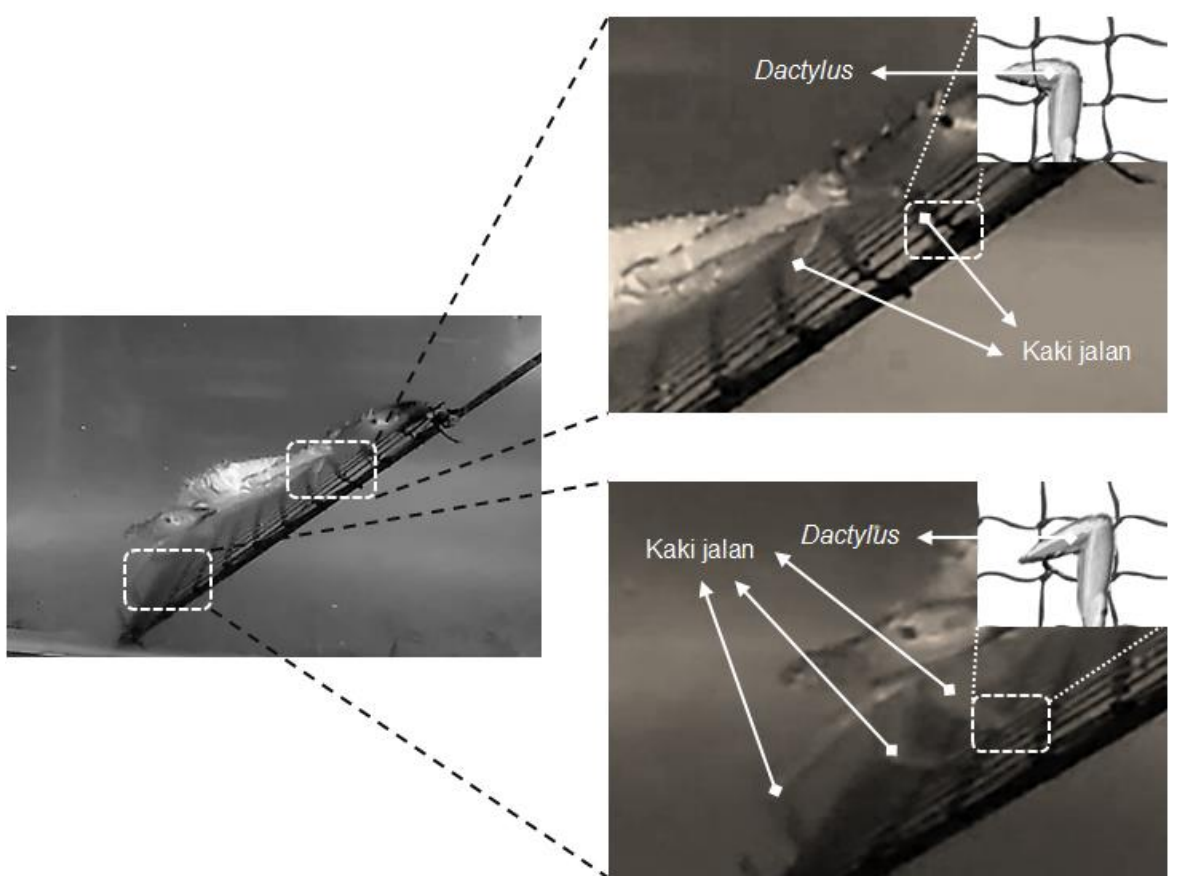

Gambar 4 Penggunaan kaki jalan rajungan saat merayap pada mata jaring satu inci dan sudut kemiringan $40^{\circ}$ 


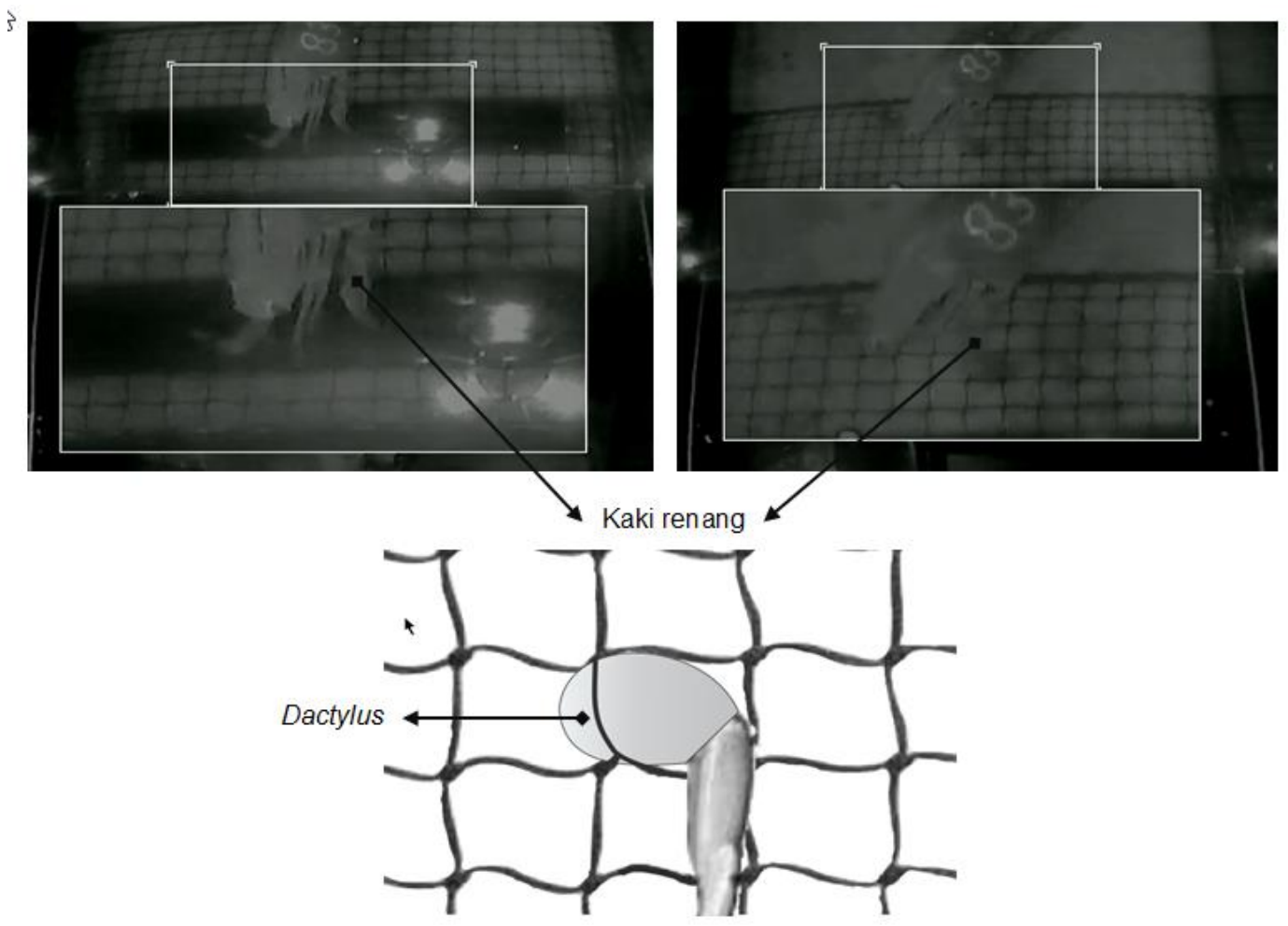

Gambar 5 Penggunaan kaki renang rajungan saat merayap pada mata jaring satu inci dan sudut kemiringan $50^{\circ}$

\section{Tingkah laku merayap rajungan}

Perbedaan ukuran mata jaring yang digunakan cenderung tidak menghasilkan pola tingkah laku rajungan yang berbeda dalam melintasi bidang jaring. Namun demikian, perbedaan sudut kemiringan bidang lintasan berpengaruh terhadap pola lintasan yang diperoleh. Posisi dominan rajungan memasuki bubu pada semua ukuran mata jaring adalah melalui sisi kiri atau kanan bidang lintasan. Pola tersebut ditemukan pada sudut $30^{\circ}$ dan $40^{\circ}$ dengan persentase dari sisi kiri masing-masing $25 \%$ dan $24 \%$ serta pada sisi kanan masing-masing sebesar $35 \%$ seperti disajikan pada Gambar 6.

Rajungan yang merayap pada sisi kiri atau kanan saat melewati bidang lintasan pada semua sudut kemiringan tidak mengalami perubahan orientasi tubuhnya (Gambar 7). Hal yang sama juga terjadi pada rajungan yang melewati bidang lintasan melalui bagian tengah frame. Perubahan orientasi tubuh terjadi pada rajungan yang melewati lintasan jaring pada jarak 1/3 lebar frame baik pada sisi kiri maupun kanannya. Pada awal pergerakannya, rajungan berhenti dan merubah orientasi tubuh dengan menghadapkan mulutnya ke arah pintu masuk. Namun demikian, rajungan hanya bertahan sesaat ketika merayap dalam posisi tersebut dan selanjutnya bergerak kembali dengan posisi yang sama hingga melewati bidang lintasan.

Perubahan tingkah laku signifikan diperoleh pada tingkah laku merayap pada sudut kemiringan $50^{\circ}$. Sebagian besar rajungan $(48 \%)$ melewati bidang lintasan dengan merayap membentuk pola diagonal. Hal ini terjadi karena semakin tinggi sudut kemiringan yang digunakan maka semakin besar pula energi yang diperlukan untuk melewati bidang jaring. Selain itu, merayap dengan pola diagonal juga menyebabkan bagian dactylus pada kaki renang rajungan tidak mudah tersangkut sehingga rajungan tidak terhambat ketika merayap melewati bidang jaring yang dipasang pada sudut kemiringan yang lebih tinggi. 

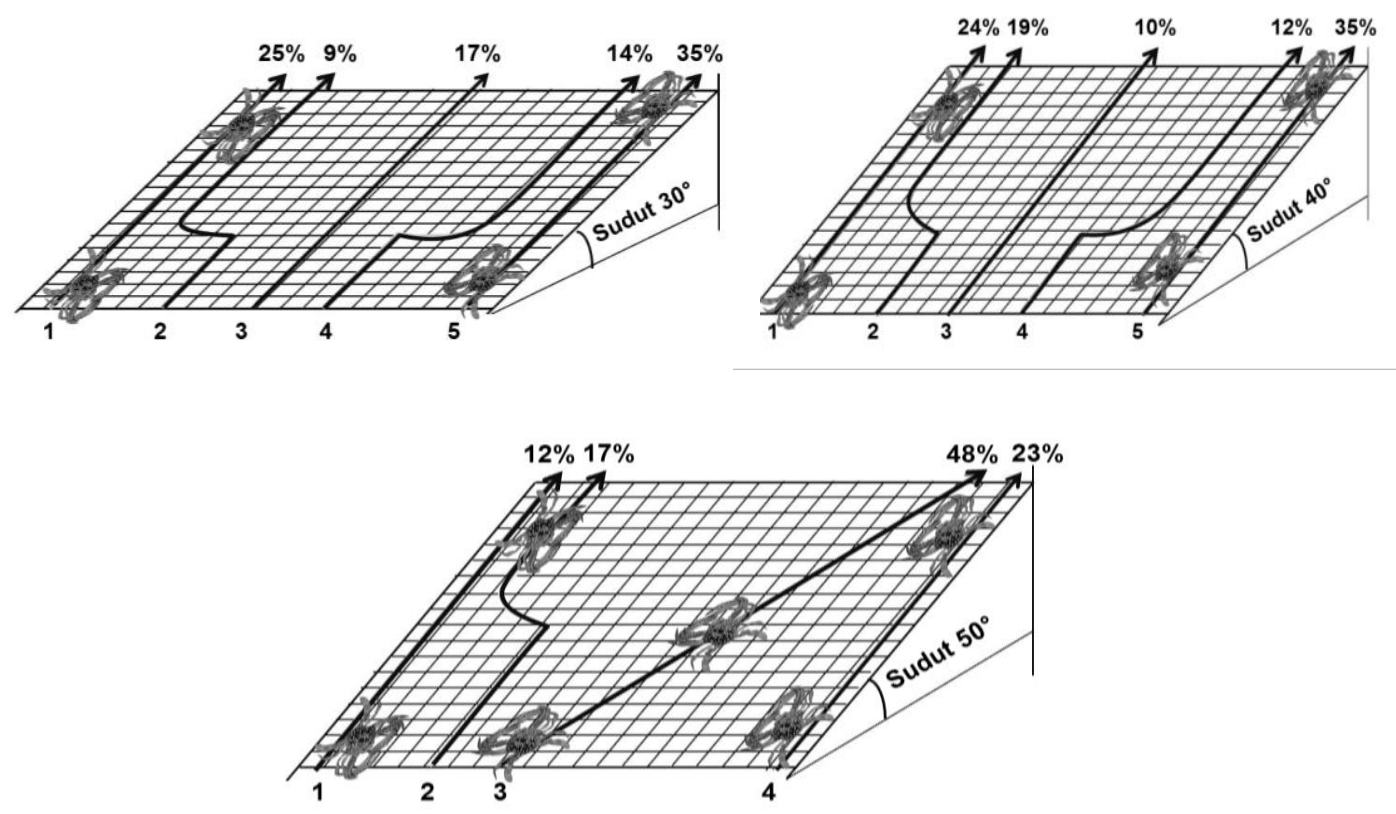

Gambar 6 Pola merayap rajungan melewati bidang lintasan jaring pada sudut kemiringan berbeda
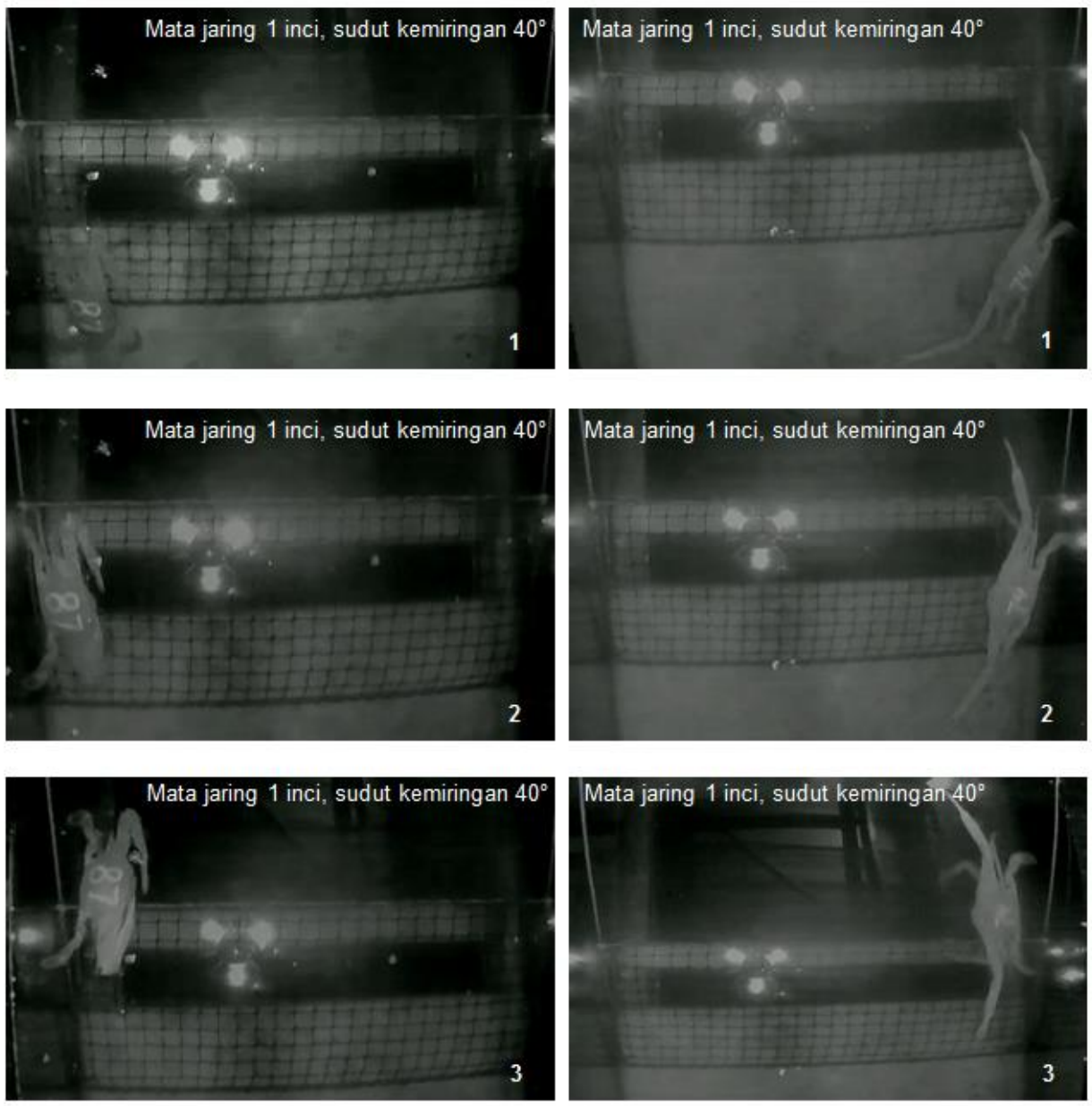

Gambar 7 Tingkah laku rajungan melewati bidang jaring melalui sisi kiri dan kanan lintasan. Rajungan mendekati/menyentuh bidang lintasan (1), rajungan merayap ditengah bidang lintasan (2), rajungan berhasil melewati bidang lintasan (3) 


\section{PEMBAHASAN}

Konstruksi pintu dan lintasan masuk bubu merupakan salah satu faktor yang menentukan keberhasilkan penangkapan ikan dengan bubu (Tran et al. 2020). Selain itu, Khikmawati et al. (2015) menambahkan bahwa konstruksi mulut bubu juga mempengaruhi produktivitas penangkapan dengan alat tangkap bubu. Perbedaan ukuran mata jaring dan sudut kemiringan mulut bubu mempengaruhi tingkat keberhasilan rajungan dalam melewati bidang lintasan. Keberhasilan rajungan melewati bidang lintasan dengan persentase yang tinggi menunjukkan bahwa konstruksi yang digunakan efektif untuk digunakan. Hal ini senada dengan hasil penelitian Sturdivant \& Clark (2011), Chalim et al. (2017) dan Rompis et al. (2019) yang menyatakan bahwa konstruksi pintu masuk yang digunakan pada alat tangkap bubu akan berpengaruh signifikan terhadap jumlah dan ukuran hasil tangkapan yang diperoleh.

Pemasangan mata jaring membentuk pola kotak menyebabkan ukuran celah jaring yang terbentang pada bidang lintasan semakin lebar seiring penambahan mata jaring. Perubahan celah mata jaring tersebut mempengaruhi tingkat keberhasilan rajungan ketika melewati bidang lintasan jaring. Ukuran celah yang terlalu kecil/ rapat akan menyulitkan rajungan merayap pada bidang lintasan karena kaki jalannya akan tersangkut pada celah mata jaring. Sebaliknya ukuran mata jaring yang terlalu lebar akan menyebabkan kaki renang rajungan terperosok sehingga menghambat rajungan ketika merayap melewati bidang lintasan. Susanto et al. (2014) dan Aditya et al. (2020) menyatakan bahwa morfologi dactylus pada kaki renang rajungan dengan bentuk yang membundar akan menyebabkan kaki renangnya tersangkut atau terperosok sehingga menyulitkan rajungan untuk merayap melewati lintasan jaring yang memiliki ukuran tidak sesuai. Kondisi tersebut menyebabkan rajungan gagal melewati lintasan pintu masuk bubu dan gagal tertangkap.

Penggunaan sudut kemiringan berbeda pada masing-masing ukuran mata jaring berpengaruh terhadap jumlah rajungan yang gagal melintas. Jumlah rajungan yang gagal melintas paling tinggi ditemukan pada penggunaan mata jaring 1,0 inci dengan sudut kemiringan $50^{\circ}$, sedangkan kegagalan paling rendah ditemukan pada mata jaring 1,25 inci dengan sudut kemiringan $30^{\circ}$. Berdasarkan hasil tersebut maka mata jaring berukuran 1,25 inci dapat direkomendasikan sebagai ukuran yang ideal untuk digunakan pada bubu lipat. Sementara itu dari sudut kemiringan, maka pintu masuk dengan sudut $40^{\circ}$ lebih direkomendasikan dibandingkankan kemiringan lainnya karena menghasilkan kecepatan merayap tertinggi $(2,04 \mathrm{~cm} / \mathrm{s})$ dibandingkan sudut kemiringan lainnya.

Susanto et al. (2014) menyatakan bahwa semakin rendah sudut kemiringan yang digunakan, maka kepiting akan lebih mudah melewati lintasan jaring. Sebaliknya Fitri et al. (2017) dan Aditya et al. (2020) menyatakan bahwa semakin terjal sudut lintasan menyebabkan kepiting dan rajungan sulit untuk melewatinya bahkan kepiting dan rajungan hanya berdiam diri di pertengahan atau bagian bawah bidang lintasan. Ujicoba penangkapan yang dilakukan Wijayanti et al. (2018) dan Utami et al. (2020) mendapatkan hasil tangkapan rajungan yang lebih banyak pada bubu lipat dengan sudut kemiringan 40$45^{\circ}$ dibandingkan dengan bubu dengan sudut kemiringan $30-35^{\circ}$. Olsen et al. (2019) menyatakan bahwa posisi dan desain pintu masuk pada bubu berpengaruh signifikan terhadap hasil tangkapan snow crab. Bubu dengan sudut pintu masuk yang curam $\left(63^{\circ}\right)$ mendapatkan hasil tangkapan snow crab $66 \%$ lebih redah dibandingkan dengan bubu dengan kemiringan pintu masuk yang rendah $\left(23^{\circ}\right)$.

Hasil penelitian Zhou \& Kruse (2000), Boutson et al. (2008), Winger \& Walsh (2011) menyatakan bahwa semakin curam sudut kemiringan mulut bubu yang digunakan, maka kecepatan merayap kepiting dan rajungan melintasi mulut bubu akan semakin rendah. Selain itu, energi yang dikeluarkan rajungan juga lebih besar saat berusaha melintasi bidang yang curam. Su et al. (2019) menyatakan bahwa pasca rajungan melakukan pergerakan/aktivitas yang membutuhkan energi tinggi, terjadi penurunan signifikan pada kadar glukosa dalam daging pada bagian badan, kaki renang dan capitnya sehingga rajungan menjadi kelelahan. Kondisi ini dapat menyebabkan rajungan berhenti beraktivitas/merayap di tengah lintasan jaring dan gagal melewati bidang jaring.

Penggunaan aspek tingkah laku rajungan sangat penting dalam menentukan desain pintu masuk bubu (sudut kemiringan dan ukuran mata jaring yang efektif (Archdale et al. 2003; 2007). Berdasarkan hasil 
penelitian maka dapat diperoleh fakta bahwa desain pada pintu masuk bubu lipat bila dilihat dari aspek ukuran mata jaring dan sudut kemiringan, dapat mempengaruhi tingkah laku rajungan ketika melewati bidang lintasan. Rajungan menyusuri dinding akuarium hingga kaki jalan dan kaki renangnya menyentuh bagian bawah bidang lintasan. Selanjutnya dengan posisi punggung menyentuh dinding akuarium rajungan merayap perlahan hingga melewati bidang jaring. Hasil senada juga diungkapkan oleh Archdale et al. (2006) yang menyatakan bahwa posisi rajungan saat memasuki bubu lipat didominasi oleh posisi menyamping dengan persentase paling tinggi sebesar $33 \%$.

Pemilihan ukuran mata jaring dan kemiringan yang sesuai, akan meningkatkan peluang tertangkapnya rajungan pada bubu. Penggunaan mata jaring yang tidak sesuai (lebih kecil atau lebih besar) dengan morfologi dan tingkah laku merayap rajungan akan menghambat laju rajungan ketika melewati bidang jaring. Sudut kemiringan yang rendah akan mudah dilewati rajungan namun peluang lolosnya rajungan melalui pintu masuk menjadi tinggi. Penggunaan sudut yang sesuai akan meningkatkan keberhasilan rajungan melewati pintu masuk dan mengurangi potensi rajungan lolos dari pintu masuk yang sama. Kombinasi ukuran mata jaring dan sudut kemiringan yang tepat akan menghasilkan desain pintu masuk yang ideal dan berpeluang meningkatkan produktivitas penangkapan rajungan dengan bubu lipat.

\section{KESIMPULAN}

Pintu masuk bubu lipat akan lebih ideal menggunakan mata jaring berukuran 1,25 inci yang dipasang pada sudut kemiringan $40^{\circ}$. Penggunaan mata jaring dan sudut kemiringan tersebut menghasilkan kecepatan merayap yang paling tinggi dan frekuensi kegagalan melintas yang paling rendah sehingga diharapkan dapat meningkatkan efektivitas penangkapan rajungan dengan bubu lipat.

\section{SARAN}

Penelitian lapangan dengan mempertimbangkan waktu dan lokasi penelitian yang berbeda sangat diperlukan untuk melakukan validasi desain yang diperoleh sehingga dapat diimplementasikan secara luas di masyarakat.

\section{UCAPAN TERIMA KASIH}

Penulis mengucapkan terima kasih kepada Direktorat Jenderal Pendidikan Tinggi, Kementerian Pendidikan, Kebudayaan, Riset dan Teknologi yang memberikan dukungan pendanaan melalui skema Hibah Riset Dasar berdasarkan kontrak No. B/564/43.9/PT.00.03/2021.

\section{DAFTAR PUSTAKA}

APRI (Asosiasi Pengelola Rajungan Indonesia). 2016. Stock Assessment, Fisheries and Environment Parameters for BSC (Portunus pelagicus) in the Java Sea. Research Report. Jakarta.

Aditya H, Mawardi W, Riyanto M. 2020. Behavior Response of Blue Swimming Crab (Portunus pelagicus) to the Different Entrance Gates of Collapsible Pot. Omni-Akuatika. 16(2): 167 -172.

Archdale MV, Anraku K, Yamamoto T, Higashitani N. 2003 Behaviour of the Japanese Rock Crab 'Ishigani' Charybdis japonica Towards Two Collapsible Baited Pots: Evaluation of Capture Effectiveness. Fisheries Science. 69: 785-791.

Archdale MV, Kariyazono I, Anasco CP. 2006. The Effect of Two Pot Types on Entrance Rate and Entrance Behavior of the Invasive Japanese Swimming Crab Charybdis japonica. Fish. Res. 77: 271274.

Archdale MV, Anasco CP, Kawamura Y, Tomiki S. 2007 Effect of Two Collapsible Pot Designs on Escape Rate and Behavior of the Invasive Swimming Crabs Charybdis japonica and Portunus pelagicus. Fisheries Research. 85: 202209.

Atar HH, Ölmes M, Bekcan S, Seçer S. 2002. Comparison of Three Different Traps for Catching Blue Crab (Callinectes sapidus Rathbun 1896) in Beymelek Lagoon. Turk Journal of Veterinary Animal Science. 26: 1145-1150.

Azra MN, Ikhwanuddin M. 2015. Larval Culture and Rearing Techniques of Commercially Important Crab, Portunus pelagicus (Linnaeus, 1758): Present Status and Future Prospects. 
Songklanakarin Journal of Science and Technology. 37: 135-145

Boutson A, Mahasawasde C, Mahasawasde S, Tunkijjanukij S, Arimoto T. 2008. Use of Escape Vents to Improve Size and Species Selectivity of Collapsible Pot for Blue Swimming Crab Portunus pelagicus in Thailand. Fish. Sci. 75: 25-33.

Chalim MA, Budiman J, Reppie. 2017. Pengaruh Bentuk Bubu Terhadap Hasil Tangkapan Rajungan (Portunus pelagicus) di Perairan Pantai Desa Kema Tiga Kabupaten Minahasan Utara Provinsi Sulawesi Utara. J. IImu dan Teknologi Perikanan Tangkap. 2(5): 176180.

Fitri ADP, Boesono $H$, Sabdono $A$, Supadminingsih FN, Adlina N. 2017. The Mud Crab (Scylla serrata) Behavior in Different Inclination Angles of Funnel and Escape Vent for Trap Net. AACL Bioflux. 10: 191-199.

Hasanah M, Fitri ADP, Pramonowibowo. 2017. Analisis Tingkah Laku Kepiting Bakau (Scylla serrata) Terhadap Perbedaan Sudut Kemiringan Pintu Masuk dan Celah Pelolosan Bubu (Skala Laboratorium). J. Perikanan Tangkap. 1(2): 48-53.

Irnawati, Yanto S, Jamaluddin. 2018. Modifikasi Alat Tangkap Rajungan (Portunus pelagicus) dalam Meningkatkan Hasil Tangkapan Nelayan. J. Pendidikan Teknologi Pertanian. 3: 3039.

Jayanto BB, Kurohman F, Boesono $\mathrm{H}$, Prihantoko KE. 2018. Analisis Hasil Tangkapan Rajungan pada Alat Tangkap Bubu Funnel 2 dan Funnel 4 di Perairan Rembang. J. Perikanan Tangkap. 2(1): 6-11.

Kembaren DD, Surahman A. 2018. Struktur Ukuran dan Biologi Populasi Rajungan (Portunus pelagicus Linnaeus, 1758) di Perairan Kepulaun Aru. JPPI. 24(1): 5160.

Khikmawati LT, Herry B, Sardiyatmo. 2015. Pengaruh Perbedaan Lama Pengoperasian dan Kemiringan Dinding Bubu terhadap Hasil Tangkapan Lobster (Panulirus sp.) di Perairan Argopeni Kabupaten Kebumen. Journal of
Fisheries Resources Utilization Management and Technology. 4(2): 8392.

Li Y, Yamamoto K, Hiraishi T, Nashimoto K, Yoshino H. 2006. Effects of Entrance Design on Catch Efficiency of Arabesque Greenling Traps: A Field Experiment in Matsumae, Hokkaido. Fisheries Science. 72: 1147-1152.

Liu D, Wang F, Lu Y, Hu N, Su X, Liu J, Zhu B. 2019. Behavioral Mechanisms of Swimming Crab (Portunus trituberculatus) Preying on Manila Clams (Ruditapes philippinarum): Effects of Substrate and Competition. Mar. Biol. 166(15):1-12.

Luhur ES, Asnawi, Arthatiani FY, Suryawati SH. 2020. Determinan Permintaan Ekspor Kepiting/Rajungan Olahan Indonesia ke Amerika Serikat: Pendekatan Error Correction Model. J. Kebijakan Sosek KP. 10(2): 131-139.

Marliana Y, Susanto A, Mustahal. 2015. Tingkat Keramahan Lingkungan Bubu Lipat yang Berbasis di Pelabuhan Perikanan Nusantara Karangantu Kota Serang Provinsi Banten. J. Perikanan dan Kelautan. 5(2): 79-84.

Mahiswara, Hufiadi, Baihaqi, Budiarti TW. 2018. Pengaruh Ukuran Mata Jaring Bubu Lipat terhadap Jumlah dan Ukuran Hasil Tangkapan Rajungan di Perairan Utara Lamongan Jawa Timur. JPPI. 24(3): 175-185.

Olsen L, Herrmann B, Grimaldo E, Sistiaga M. 2019. Effect of Pot Design on the Catch Efficiency of Snow Crabs (Chionoecetes opilio) in the Barents Sea fishery. PLoSONE. 14(7): e0219858.

Putri RLC, Fitri ADP, Yulianto T. 2013. Analisis Perbedaan Jenis Umpan dan Lama Waktu Perendaman pada Alat Tangkap Bubu terhadap Hasil Tangkapan Rajungan di Perairan Suradadi Tegal. J. of Fish. Resources Utilization Man. and Tech. 2(3): 51-60.

Rompis J, Paransa IJ, Pamikiran RDC. 2019. Pengaruh Posisi Pintu Masuk (Entrance) Bubu Apung terhadap Hasil Tangkapan pada Rumpon Laut Dangkal. J. Ilmu dan Teknologi Perikanan Tangkap. 4(1): 1-5. 
Suhana. 2020. Melihat Kepiting-Rajungan di Pasar USA. Retrieved from https://suhana.web.id/2020/02/20/meliha t-kepiting-rajungan-di-pasar-usa/.

Diakses tanggal 4 September 2021.

Su X, Sun Y, Liu D, Wang F, Liu J, Zhu B. 2019. Agonistic Behaviour and Energy Metabolism of Bold and Shy Swimming Crabs Portunus trituberculatus. J. of Exp.I Biol. 222: 1-8.

Sun Y, Wang F, Hu N, Su X, Liu Z, Dircksen H. 2017. Prey Selection of the Swimming Crab Portunus trituberculatus (Miers, 1876) (Brachyura: Portunidae) Foraging on Bivalves. Journal of Crustacean Biology. 37(5): 521-528.

Susanto A, Irnawati R, Sasmita A. 2014. Identifikasi Kecepatan Merayap Kepiting Bakau (Scylla serrata) Pada Bentuk Mata Jaring dan Sudut Kemiringan yang Berbeda. JIPP. 3(1): 11-17.

Susanto A, Baskoro MS, Wisudo SH. Riyanto M, Purwangka F. 2018. Penentuan Warna dan Intensitas Lampu Light Emiitting Diode (LED) yang Optimum Pada Penangkapan Ikan Selar Kuning (Selaroides leptolepis) untuk Perikanan Bagan Tancap. Marine Fisheries. 9(2): 145-155.

Susanto A, Irnawati R, Mustahal, Sutrawan HN, Marliana Y, Kurniasih A, Widowati N, Murniasih TY, Affandi N. 2019. Meta Analisis Pengaruh Tekanan Penangkapan terhadap Ukuran Rajungan (Portunus pelagicus) di Teluk Banten. Marine Fisheries. 10(2): 53-163.

Sturdivant SK, Clark KL. 2011. An Evaluation of the Effects of Blue Crab (Callinectes sapidus) Behavior on the of Crab Efficacy Pots as a Tool for Estimating Population Abundance. Fish Bul. 109: 48-55.

Tran PD, Nguyen LT, To PV, Nguyen KQ. 2020. Effects of the Trap Entrance Designs on the Catch Efficiency of Swimming Crab Charybdis feriata Fishery. Fisheries Research. 232(105730): 1-9.

Utami WD, Zulkarnain, Martasuganda S, Kurniawati VR. 2020. Experimental Fishing Bubu Lipat Modifikasi Konstruksi Dua Pintu untuk Penangkapan Rajungan (Portunus spp). Albacore. 4(1): 83-95.

Wijayanti N, Hamdani H, Prihadi J, Dewanti LP. 2018. Studi Pengaruh Perbedaan Konstruksi Mulut Bubu Lipat terhadap Hasil Tangkapan Rajungan (Portunus pelagicus) di Perairan Karangsog, Indramayu. J. Perikanan dan Kelautan. 9(2): 54-63.

Winger PD, Walsh PJ. 2011. Selectivity, Efficiency, and Underwater Observations of Modified Trap Designs for the Snow Crab (Chionoecetes opilio) Fishery in Newfoundland and Labrador. Fisheries Research. 109(1): 107-113. Zhua B, Lu $Y$, Wang $F$, Liua D, Sua X, Shanga Y. 2021. Will Swimming Crab Change Their Territoriality when Prey Density Increases?. Journal of Experimental Marine Biology and Ecology. 539(151546): 1-8.

Zhou S, Kruse GH. 2000. Capture Efficiency and Selectivity of Two Types of Pots for Red King Crabs in the Bering Sea. Alaska Fish Res Bull. 6(2): 94-103. 